\title{
Precipitation of salts in freezing seawater and ozone depletion events: a status report
}

\author{
S. Morin ${ }^{1,2}$, G. M. Marion ${ }^{3}$, R. von Glasow ${ }^{4}$, D. Voisin ${ }^{1,2}$, J. Bouchez ${ }^{1,5}$, and J. Savarino ${ }^{1,2}$ \\ ${ }^{1}$ CNRS, Institut National des Sciences de l'Univers, France \\ ${ }^{2}$ Université Joseph Fourier - Grenoble 1, Laboratoire de Glaciologie et Géophysique de l'Environnement, Grenoble, France \\ ${ }^{3}$ Desert Research Institute, Reno, NV, USA \\ ${ }^{4}$ School of Environmental Sciences, University of East Anglia, Norwich, UK \\ ${ }^{5}$ Université Paris Diderot, Institut de Physique du Globe de Paris, Équipe de Géochimie-Cosmochimie, Paris, France
}

Received: 12 March 2008 - Published in Atmos. Chem. Phys. Discuss.: 20 May 2008

Revised: 7 October 2008 - Accepted: 17 November 2008 - Published: 11 December 2008

\begin{abstract}
In springtime, the polar marine boundary layer exhibits drastic ozone depletion events (ODEs), associated with elevated bromine oxide $(\mathrm{BrO})$ mixing ratios. The current interpretation of this peculiar chemistry requires the existence of acid and bromide-enriched surfaces to heterogeneously promote and sustain ODEs. Sander et al. (2006) have proposed that calcium carbonate $\left(\mathrm{CaCO}_{3}\right)$ precipitation in any seawater-derived medium could potentially decrease its alkalinity, making it easier for atmospheric acids such as $\mathrm{HNO}_{3}$ and $\mathrm{H}_{2} \mathrm{SO}_{4}$ to acidify it. We performed simulations using the state-of-the-art FREZCHEM model, capable of handling the thermodynamics of concentrated electrolyte solutions, to try to reproduce their results, and found that when ikaite $\left(\mathrm{CaCO}_{3} \cdot 6 \mathrm{H}_{2} \mathrm{O}\right)$ rather than calcite $\left(\mathrm{CaCO}_{3}\right)$ precipitates, there is no such effect on alkalinity. Given that ikaite has recently been identified in Antarctic brines (Dieckmann et al., 2008), our results show that great caution should be exercised when using the results of Sander et al. (2006), and reveal the urgent need of laboratory investigations on the actual link(s) between bromine activation and the $\mathrm{pH}$ of the surfaces on which it is supposed to take place at subzero temperature. In addition, the evolution of the $\mathrm{Cl} / \mathrm{Br}$ ratio in the brine during freezing was computed using FREZCHEM, taking into account $\mathrm{Br}$ substitutions in $\mathrm{Cl}$-containing salts.
\end{abstract}

\section{Introduction}

Boundary layer ozone depletion events (ODEs) in early springtime are a widespread and recurring phenomenon in

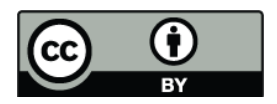

Correspondence to: S. Morin (samuel.morin@ujf-grenoble.fr) the polar marine boundary layer, both in the Arctic and Antarctic (e.g. Simpson et al., 2007, and references therein). Ozone $\left(\mathrm{O}_{3}\right)$ is known to be destroyed through an autocatalytic mechanism involving halogen radicals and oxides, in particular bromine and bromine oxide $(\mathrm{Br} / \mathrm{BrO})$. While the understanding of the gas-phase mechanism accounting for the destruction of ozone under these conditions seems to be fairly complete (Bottenheim et al., 2002), the exact nature of the medium on which $\mathrm{Br}$ is activated (from sea-salt bromide into atmospheric bromine) is still unresolved. $\mathrm{Br}$ radicals rapidly react with $\mathrm{O}_{3}$ to form $\mathrm{BrO}$. Under ODE conditions, $\mathrm{BrO}$ mainly self-reacts (yielding the photolabile compound $\mathrm{Br}_{2}$ ) or reacts with $\mathrm{HO}_{2}$ to produce $\mathrm{HOBr}$. $\mathrm{HOBr}$ is watersoluble and thus is taken up into aqueous media to react with available bromide in the presence of acidity (Fan and Jacob, 1992; Fickert et al., 1999):

$\mathrm{HOBr}+\mathrm{Br}^{-}+\mathrm{H}^{+} \rightarrow \mathrm{Br}_{2}+\mathrm{H}_{2} \mathrm{O}$

$\mathrm{Br}_{2}$ is highly insoluble and therefore is released into the atmosphere, where its photolysis yields two $\mathrm{Br}$ radicals, both of which can in turn react with ozone. By exponentially increasing the amount of atmospheric reactive bromine, this mechanism is the backbone of the so-called bromine explosion (Platt and Janssen, 1995) and the associated quantitative ozone destruction. The medium where Reaction (R1) occurs must fulfill the three following conditions:

1. Be at the interface between the gas phase and a phase containing available bromide,

2. Have a sufficiently large surface area (accessible to gases),

3. Feature a pH low enough for Reaction (R1) to occur at a significant rate.

Published by Copernicus Publications on behalf of the European Geosciences Union. 
(i) Brine aerosol production due to splashing

(ii) Aerosol production from FF due to wind action

(iii) Gas phase release of bromine via within-snow

bromine explosion due to upward migrating brine

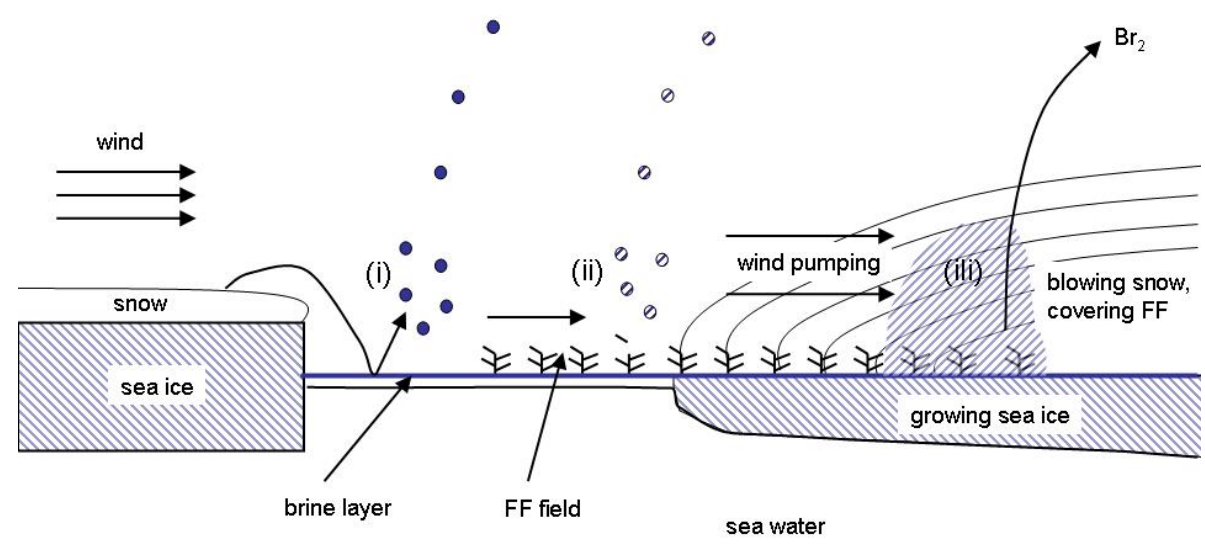

Fig. 1. Sketch of three likely processes resulting in an impact of chemical fractionation occurring during the freezing of seawater on the chemical composition of surfaces undergoing bromine explosion.

Simpson et al. (2007) thoroughly discussed the nature of media fulfilling the above-mentioned conditions. Frostflowers grow by addition of water vapour from the atmosphere on very thin sea ice that typically has high loadings of brine at its surface. Marine aerosols, frost-flowers (or frostflower derived aerosols) and sea-salt enriched snowpack derive from seawater, which is known to be alkaline (Zeebe and Wolf-Gladrow, 2001). Its $\mathrm{pH}$ is generally buffered by the carbonate system (i.e. thermodynamic equilibria between atmospheric $\mathrm{CO}_{2}$ and dissolved $\mathrm{CO}_{2}, \mathrm{HCO}_{3}^{-}$and $\mathrm{CO}_{3}^{2-}$ ), within $0.1-0.2 \mathrm{pH}$-units around an average value of 8.2 at the surface. Because of the high amount of salts dissolved in it (its average salinity $S$ (Millero et al., 2008) being 35), seawater does not entirely freeze solid when exposed to subzero temperature. The formation of ice is accompanied by a "saltingout" of ions into an increasingly concentrated brine, as temperature decreases. For example, at $-10^{\circ} \mathrm{C}$, the salinity of brine is $144 \mathrm{~g} \mathrm{~kg}^{-1}$, which represents a four-fold increase in salinity (Richardson, 1976). Along this gradual concentration process, some salts reach their solubility threshold and start precipitating.

In polar regions, chemical fractionation associated with the precipitation of salts primarily of marine origin significantly affects the chemical composition of aerosols. In the brine, mirabilite $\left(\mathrm{Na}_{2} \mathrm{SO}_{4} \cdot 10 \mathrm{H}_{2} \mathrm{O}\right)$ has been shown to precipitate below $-8^{\circ} \mathrm{C}$ (Richardson, 1976; Weeks and Ackley, 1982). The observation that sulfate is depleted in atmospheric particles in coastal Antarctica ("negative non-seasalt sulfate") was linked to mirabilite precipitation in the brine (Wagenbach et al., 1998). Since calcium carbonate and mirabilite are likely to precipitate under almost similar con- ditions, it is expected that carbonate precipitation could have a major impact on the composition of atmospheric aerosols likewise. Figure 1 summarizes the proposed mechanisms by which chemical fractionation occurring during the freezing of seawater could have an impact on the chemical composition of polar aerosols and reactive surfaces. The processes depicted are (i) aerosol production through splashing of brine droplets when wind-blown snow/ice crystals impinge on the brine surface; (ii) breaking-off of micro-branches of frost flowers due to wind action; brine is being wicked up on frost flowers and therefore the frost-flowers, and potential aerosol formed from them, are coated with brine; (iii) withinsnowpack bromine explosion: wind-blown snow might cover an area with brine/frost flowers, wicking up the brine into the firn where a bromine explosion might occur in the interstitial air. The main difference between these processes is that (i) and (ii) would lead to the production of bromine-containing aerosol particles whereas in (iii) bromine would be released from the snow pack into the atmosphere as photolysable gas phase compound (e.g. $\mathrm{Br}_{2}$ or $\mathrm{BrCl}$ ). The key commonality of the three processes is that a physical separation of the brine and all precipitates is occuring. It is currently believed that processes affecting the chemical composition of seawater brine during the freezing process should translate in some ways to the media on which bromine activation is supposed to take place.

Sander et al. (2006) have proposed that calcium carbonate $\left(\mathrm{CaCO}_{3}\right)$ precipitation in the brine at subzero temperatures could efficiently remove most of the seawater alkalinity, hence annihilating its buffering capacity. As a consequence, small amounts of acids present in the atmosphere (such as 
$\mathrm{HNO}_{3}$ and $\mathrm{H}_{2} \mathrm{SO}_{4}$ ) would easily lower the $\mathrm{pH}$ enough for Reaction (R1) to proceed at an accelerated rate. Piot and von Glasow (2008) have included this process in their modeling study on the conditions necessary to trigger and sustain ozone depletion, and have found that the alkalinity depletion rate was a critical factor for the onset and the sustainment of ODEs. However, Sander et al. (2006) calculated the fraction of remaining alkalinity in brine as a function of temperature using the data of Richardson (1976) for major ion concentrations and computing variables relevant to the carbonate system using thermodynamic constants only valid above $0^{\circ} \mathrm{C}$ and for a salinity of 35 . The validity of their results may therefore be questioned, in a context of strongly non-ideal solutions where elevated activity corrections must be considered to correctly account for chemical equilibria. Of particular relevance to this is the recent experimental discovery that ikaite $\left(\mathrm{CaCO}_{3} \cdot 6 \mathrm{H}_{2} \mathrm{O}\right)$, and not calcite $\left(\mathrm{CaCO}_{3}\right)$, is the mineral most likely to precipitate in freezing seawater (Dieckmann et al., 2008), in contradiction with earlier reports (Marion, 2001, and references therein).

An additional potentially important effect relevant to atmospheric chemistry, associated with precipitation of ions in seawater during freezing, is the different behavior of halogen anions. Indeed, chloride and bromide are not expected to precipitate at the same temperatures. Assuming that bromide was never precipitating during freezing, while chloride precipitates as $\mathrm{NaCl} \cdot 2 \mathrm{H}_{2} \mathrm{O}$ below $-22^{\circ} \mathrm{C}$, Koop et al. (2000) speculated that this could cause a net enrichment of bromide over chloride in the brine, thus providing better conditions for the bromine activation mechanism (Vogt et al., 1996).

In the present study, we investigate the thermodynamics of seawater brine at subzero temperatures, with a focus on the behavior of the carbonate system and on the chloride/bromide ratio. Our approach relies on the use of the molal-based thermodynamic model FREZCHEM, specifically designed to handle non-ideal solutions using the Pitzer formalism and using state-of-the-art equilibrium constants (see Marion, 2001, and references therein). This allows to predict with a much greater confidence the fate of alkalinity in brine, as a function of temperature, during seawater freezing.

Taking into account the specific chemistry of bromide, we also give more accurate estimates of the $\mathrm{Cl} / \mathrm{Br}$ ratio in bulk brine, as a function of temperature.

\section{Methods}

\subsection{The FREZCHEM model}

To evaluate equilibrium chemistry for seawater freezing, we used the FREZCHEM model (Marion et al., 1999; Marion, 2001; Marion and Kargel, 2008). FREZCHEM is an equilibrium chemical thermodynamic model parameterized for concentrated electrolyte solutions using the
Pitzer equations (Pitzer, 1991, 1995) for the temperature range from $<-70$ to $25^{\circ} \mathrm{C}$ and the pressure range from 1 to 1000 bars. The model is currently parameterized for the $\mathrm{Na}-\mathrm{K}-\mathrm{Mg}-\mathrm{Ca}-\mathrm{Fe}$ (II) $-\mathrm{Fe}$ (III) $-\mathrm{H}-\mathrm{Cl}-\mathrm{Br}-\mathrm{SO}_{4}-\mathrm{NO}_{3}-$ $\mathrm{OH}-\mathrm{CO}_{3}-\mathrm{CO}_{2}-\mathrm{O}_{2}-\mathrm{CH}_{4}-\mathrm{H}_{2} \mathrm{O}$ system. It includes 81 solid phases including ice, 14 chloride minerals, 30 sulfate minerals, 15 carbonate minerals, five solid-phase acids, three nitrate minerals, six acid-salts, five iron oxides, and two gas hydrates. Details pertaining to the formalism used and the computation scheme implemented in FREZCHEM are given in Marion (2001) and Marion and Kargel (2008).

2.2 The carbonate system in seawater and its thermodynamic properties

The intricate chemical equilibrium between carbonate species in seawater and atmospheric $\mathrm{CO}_{2}$ is represented by the following three equations:

$$
\begin{aligned}
\mathrm{CO}_{2 \mathrm{gas}} & \leftrightarrow \mathrm{CO}_{2 \mathrm{aq}} \\
\mathrm{CO}_{2 \mathrm{aq}}+\mathrm{H}_{2} \mathrm{O}_{\text {liq }} & \leftrightarrow \mathrm{HCO}_{3}^{-}+\mathrm{H}^{+} \\
\mathrm{HCO}_{3}^{-} & \leftrightarrow \mathrm{CO}_{3}^{2-}+\mathrm{H}^{+}
\end{aligned}
$$

These thermodynamic equilibria are described by a Henry's law coefficient $\left(\mathrm{K}_{\mathrm{CO}_{2}}\right.$, for Reaction $\left.\mathrm{R} 2\right)$ and two dissociation constants $\left(\mathrm{Ka}_{1}\right.$ and $\mathrm{Ka}_{2}$ for Reactions $\mathrm{R} 3$ and $\mathrm{R} 4$, respectively):

$$
\begin{aligned}
\mathrm{K}_{\mathrm{CO}_{2}} & =\frac{\mathrm{a}\left(\mathrm{CO}_{2 \mathrm{aq}}\right)}{f\left(\mathrm{CO}_{2}\right)} \\
\mathrm{Ka}_{1} & =\frac{\mathrm{a}\left(\mathrm{HCO}_{3}^{-}\right) \cdot \mathrm{a}\left(\mathrm{H}^{+}\right)}{\mathrm{a}\left(\mathrm{CO}_{2 \mathrm{aq}}\right) \cdot \mathrm{a}\left(\mathrm{H}_{2} \mathrm{O}_{\mathrm{liq}}\right)} \\
\mathrm{Ka}_{2} & =\frac{\mathrm{a}\left(\mathrm{CO}_{3}^{2-}\right) \cdot \mathrm{a}\left(\mathrm{H}^{+}\right)}{\mathrm{a}\left(\mathrm{HCO}_{3}^{-}\right)}
\end{aligned}
$$

where $a(X)$, referring to the chemical activity of the species $\mathrm{X}$, is here taken equal to $\gamma_{\mathrm{X}} \cdot \mathrm{m}(\mathrm{X}) \cdot \gamma_{\mathrm{X}}$ is the activity coefficient of the species $\mathrm{X}$ and $\mathrm{m}(\mathrm{X})$ represents its molality (in mol kg $\left.\mathrm{water}^{-1}\right) . f\left(\mathrm{CO}_{2}\right)$ is the fugacity of $\mathrm{CO}_{2}$, equal to $\gamma_{\mathrm{CO}_{2}} \cdot p\left(\mathrm{CO}_{2}\right), p\left(\mathrm{CO}_{2}\right)$ being the partial pressure of $\mathrm{CO}_{2}$.

The solubility of calcium carbonate (Ksp) and the water autoprotolysis product $(\mathrm{Kw})$ are also important for the carbonate system:

$$
\begin{aligned}
& \mathrm{Ksp}=\mathrm{a}\left(\mathrm{Ca}^{2+}\right) \cdot \mathrm{a}\left(\mathrm{CO}_{3}^{2-}\right) \\
& \mathrm{Kw}=\frac{\mathrm{a}\left(\mathrm{H}^{+}\right) \cdot \mathrm{a}\left(\mathrm{OH}^{-}\right)}{\mathrm{a}\left(\mathrm{H}_{2} \mathrm{O}_{\text {liq }}\right)}
\end{aligned}
$$

Like any true thermodynamic constant, $\mathrm{K}_{\mathrm{CO}_{2}}, \mathrm{Ka}_{1}, \mathrm{Ka}_{2}$, $\mathrm{Ksp}$ and $\mathrm{Kw}$ vary as a function of the state variables temperature $(T)$ and pressure $(P)$ only. In the case of seawater freezing at the air/sea interface, we neglect the pressure dependency, so that all true thermodynamic constants presented here depend only on temperature. Ksp is specific to each calcium carbonate mineral (see below and Fig. 2). 


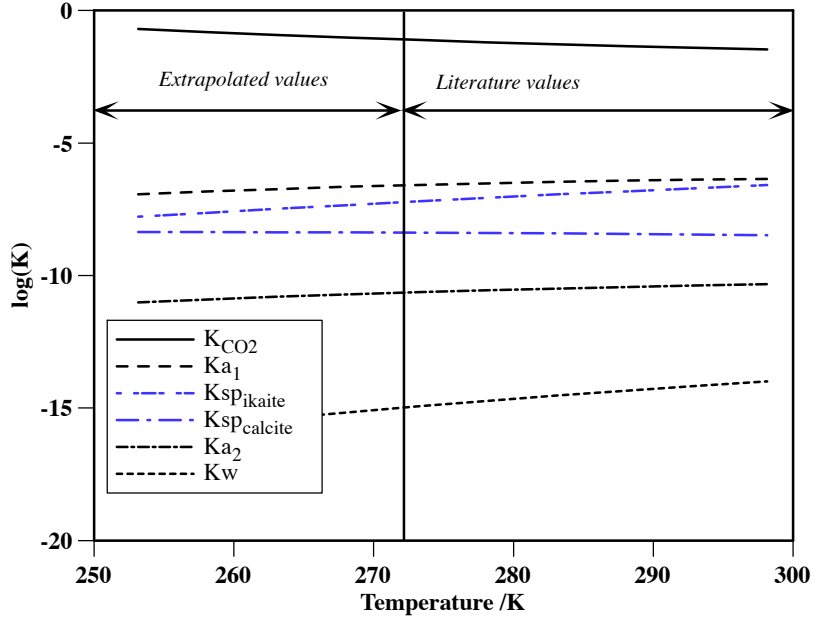

Fig. 2. Temperature dependency of thermodynamic constants relevant to the carbonate system (from Marion, 2001). Data used for plotting this graph are given as a supplementary online material. http://www.atmos-chem-phys.net/8/7317/2008/ acp-8-7317-2008-supplement.pdf

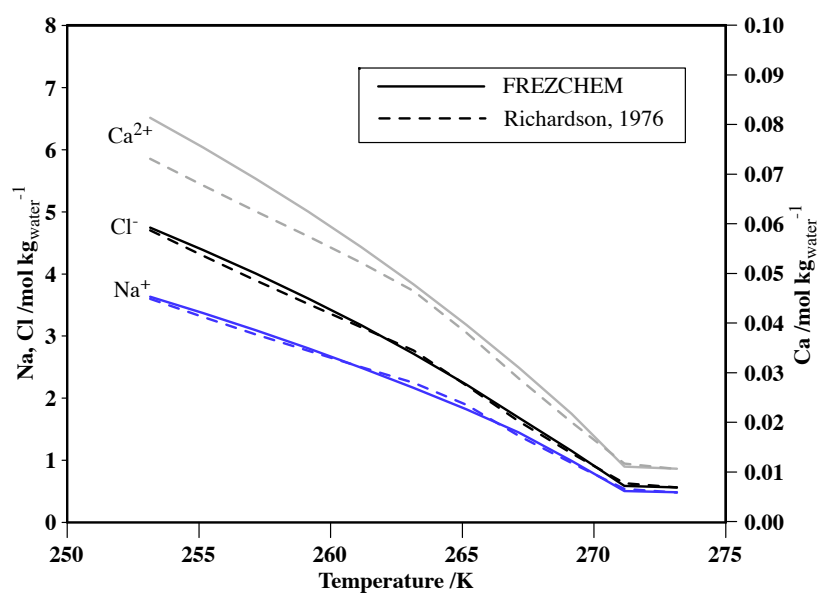

Fig. 3. Comparison of the evolution of the molality of major ions during freezing computed by FREZCHEM and measured by Richardson (1976).

\subsection{Extrapolating to subzero temperatures}

Freezing seawater simulations require parameterizations of equilibrium constants to subzero temperatures. Sander et al. (2006) noticed that using published parameterizations accounting for variations of apparent thermodynamic constants as a function of temperature or salinity out of their validity range, both in terms of temperature and salinity, led to inconsistent results. In the current study only "true" thermodynamic constants relevant to the carbonate system are extrapolated as a function of the temperature (Fig. 2). Justification and validation of these extrapolations are discussed in Marion (2001) and Marion and Kargel (2008). The key argument is that the smoothness of the curves at $T \geq 273 \mathrm{~K}$ should extrapolate well.

\subsection{Identification of the carbonate salt that precipitates}

Ikaite $\left(\mathrm{CaCO}_{3} \cdot 6 \mathrm{H}_{2} \mathrm{O}\right)$ has recently been clearly demonstrated to precipitate in brines collected on Antarctic sea ice (Dieckmann et al., 2008). This discovery has been claimed to close decades of controversies related to the nature of the carbonate mineral precipitating during the freezing of seawater (Marion, 2001; Marion et al., 2008; Dieckmann et al., 2008 , and references therein). Calcite $\left(\mathrm{CaCO}_{3}\right)$ is supersaturated in natural seawater (Marion, 2001), and its precipitation is inhibited by various dissolved ions, such as phosphate (Bischoff et al., 1993). In contrast, ikaite is undersaturated in seawater above freezing temperatures. The thermodynamic properties of these two calcium carbonate salts are also very different, in terms of their solubility: while the solubility of calcite increases with decreasing temperatures, ikaite becomes less soluble when the temperature decreases (Fig. 2). Because the precipitation kinetics and the thermodynamics of these two polymorphs of $\mathrm{CaCO}_{3}$ are so different, the nature of the calcium carbonate salt precipitating during freezing of seawater is likely to drive major changes in the behavior of the carbonate system during freezing.

We thus investigate here the fate of the alkalinity of the brine as a function of temperature during freezing, at thermodynamic equilibrium, in the case where calcite and ikaite, respectively, are assumed to be the calcium carbonate mineral that precipitates.

\section{Results}

The present study focuses on the results obtained from two model runs, simulating the freezing of seawater. Table 1 summarizes the data used for seawater compositions that were inputs to the FREZCHEM model, taken from a recent reevaluation of the composition of standard seawater at $S=35.00$ (Millero et al., 2008). In run 1, calcite is assumed to be the only carbonate mineral salt that precipitates, while in run 2 ikaite only is allowed to precipitate, using the method described by Marion (2001) to select the salts allowed to precipitate in a given FREZCHEM run.

\subsection{Major ions in seawater brine during freezing}

The composition of seawater during freezing to $253 \mathrm{~K}$, computed using FREZCHEM (run 1), is compared to the Richardson (1976) data for $\mathrm{Na}^{+}, \mathrm{Cl}^{-}$, and $\mathrm{Ca}^{2+}$ (Fig. 3). The $\mathrm{Na}^{+}$and $\mathrm{Cl}^{-}$comparisons are excellent. The model $\mathrm{Ca}^{2+}$ concentration deviates slightly from the Richardson value (Fig. 3). At $253 \mathrm{~K}$, the Richardson datapoint for $\mathrm{Ca}^{2+}$ is $0.073 \mathrm{~mol} \mathrm{~kg}_{\text {water }}{ }^{-1}$, while the FREZCHEM estimate is $0.080 \mathrm{~mol} \mathrm{~kg}_{\text {water }}{ }^{-1}$. Even if we assume that all 
Table 1. Initial composition of seawater used for the simulation ( $S=35.00$, Millero et al., 2008). The atmospheric $\mathrm{CO}_{2}$ pressure was fixed at $0.38 \cdot 10^{-3}$ bar (380 ppmv).

\begin{tabular}{llll}
\hline & $\begin{array}{l}\text { Cations } \\
\text { Initial molality }\end{array}$ & $\begin{array}{l}\text { Anions } \\
\text { Initial molality }\end{array}$ \\
\hline $\mathrm{Na}^{+}$ & 0.48606 & $\mathrm{Cl}^{-}$ & 0.56577 \\
$\mathrm{Mg}^{2+}$ & 0.05474 & $\mathrm{SO}_{4}^{2-}$ & 0.02926 \\
$\mathrm{Ca}^{2+}$ & 0.01066 & $\mathrm{Br}^{-}$ & 0.00087 \\
$\mathrm{~K}^{+}$ & 0.01058 & $\mathrm{HCO}_{3}^{-}+2 \mathrm{CO}_{3}^{2-}$ & 0.00228 \\
\hline
\end{tabular}

the carbonate ions had precipitated as calcium carbonate by $253 \mathrm{~K}$, the residual $\mathrm{Ca}^{2+}$ molality in our simulation would only be reduced to $0.079 \mathrm{~mol} \mathrm{~kg}_{\text {water }}{ }^{-1}$. A possible explanation for the discrepancy in $\mathrm{Ca}^{2+}$ values at $253 \mathrm{~K}$ could be minor differences in the initial concentrations for our ions (Table 1) and the Richardson (1976) database. But, if we run our simulation at the Richardson (1976) $\mathrm{Ca}^{2+}$ concentration $\left(0.01055 \mathrm{~mol}_{\text {water }}{ }^{-1}\right)$, that only reduces the modelcalculated $\mathrm{Ca}^{2+}$ concentration at $253 \mathrm{~K}$ from 0.080 (Fig. 3) to $0.079 \mathrm{~mol}_{\text {water }}{ }^{-1}$. Combined uncertainties on chemical analysis of brines and in theoretical thermodynamic estimates are probably the main explanation for this slight discrepancy. The nature of the calcium carbonate salt that precipitates has no impact on the evolution of the major ion composition of the brine during freezing.

\subsection{Alkalinity of brine as a function of temperature}

Seawater alkalinity is dominated by the carbonate system (Zeebe and Wolf-Gladrow, 2001). In this work, the contribution from borate and other weak acids is neglected. Therefore, we define the total alkalinity (TA, in eq $\mathrm{kg}_{\mathrm{water}}^{-1}$, where eq refer to charge equivalents) as:

$\mathrm{TA}=\mathrm{m}\left(\mathrm{OH}^{-}\right)+\mathrm{m}\left(\mathrm{HCO}_{3}^{-}\right)+2 \mathrm{~m}\left(\mathrm{CO}_{3}^{2-}\right)-\mathrm{m}\left(\mathrm{H}^{+}\right)$

In standard seawater and in the brine during freezing, TA is dominated by carbonate species because $\mathrm{H}^{+}$and $\mathrm{OH}^{-}$do not significantly contribute to it. Results from the model runs pertaining to the carbonate system are only presented in the temperature range from 273 to $253 \mathrm{~K}$, where the extrapolation of thermodynamic properties of carbonate salts to subzero temperatures is the safest (Marion, 2001). In this range, $\mathrm{HCO}_{3}^{-}$contributes over $90 \%$ of the alkalinity for both model runs.

\subsubsection{Run 1: calcite precipitation}

In run 1 , only calcite was considered to be the calcium carbonate mineral able to precipitate during freezing (Gitterman, 1937; Richardson, 1976; Marion, 2001). In this case, the FREZCHEM model has to be adapted to cope with the

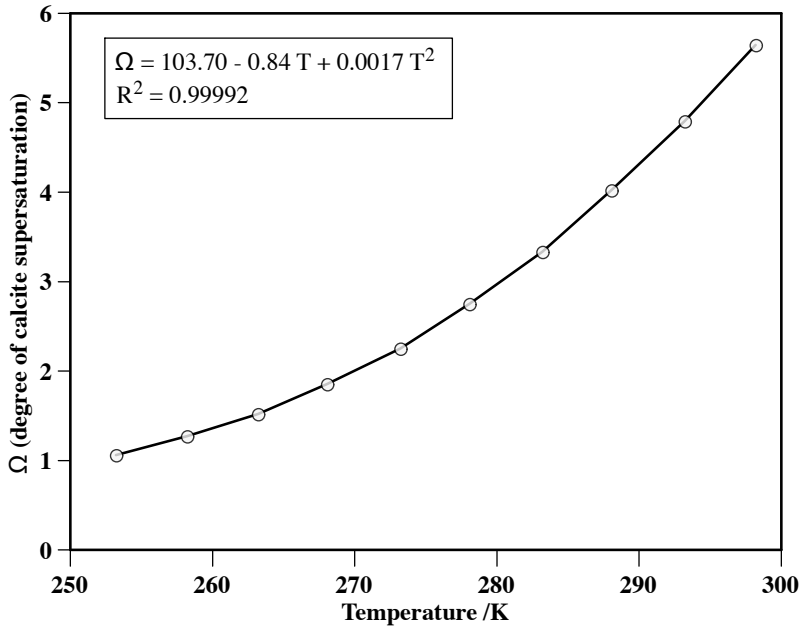

Fig. 4. Temperature dependency of the degree of supersaturation of calcite $(\Omega)$ during cooling.

fact that seawater is supersaturated with respect to many carbonate minerals (e.g., dolomite, magnesite, and calcite; Morse and Mackenzie, 1990; Millero and Sohn, 1992; Marion, 2001). One can assess the degree of supersaturation by the equation:

$\Omega=\frac{\mathrm{IAP}}{\mathrm{Ksp}}$

where IAP is the model-calculated ion activity product and Ksp is the mineral solubility product. With the composition in Table 1, we estimated the $\Omega$ value for calcite supersaturation using the FREZCHEM model; these $\Omega$ estimates ranged from 5.7 at $298 \mathrm{~K}$ to 1.1 at $253 \mathrm{~K}$ (Fig. 4). In what follows, we use the $\Omega$ value (Eq. 7, Fig. 4) as a Ksp multiplier to estimate a hypothetical solution IAP. The solutions will remain supersaturated (no calcite precipitation) until the aforementioned hypothetical solution IAP is exceeded by the newly calculated IAP due to freezing.

During freezing, along with the precipitation of calcite (predicted to start at ca. $271 \mathrm{~K}$ ), TA is reduced (Fig. 5). Starting with $2.20 \mathrm{meq} \mathrm{kg}_{\text {water }}{ }^{-1}$ at $273 \mathrm{~K}$, it is reduced to $1.19 \mathrm{meq} \mathrm{kg}_{\text {water }}{ }^{-1}$ at $263 \mathrm{~K}$, and $0.73 \mathrm{meq} \mathrm{kg}_{\text {water }}{ }^{-1}$ at $253 \mathrm{~K}$. This corresponds to a decrease of $46 \%$ and $66 \%$ of $\mathrm{TA}$, respectively. In other words, the alkalinity of brine is reduced to about half or a third of the alkalinity of seawater at $273 \mathrm{~K}$, at $263 \mathrm{~K}$ and $253 \mathrm{~K}$, respectively.

Thus in the case where calcite only is allowed to precipitate in the carbonate system, FREZCHEM predicts a larger effect of carbonate precipitation on the alkalinity of brine than Sander et al. (2006), who predicted that even at $250 \mathrm{~K}$ the concentration (in $\mathrm{mol} \mathrm{L}^{-1}$ ) of $\mathrm{HCO}_{3}^{-}$was reduced to only half of its value at $273 \mathrm{~K}$. If calcite is the mineral that precipitates during seawater freezing, our model results corroborate the conclusions of the study by Sander et al. (2006). 


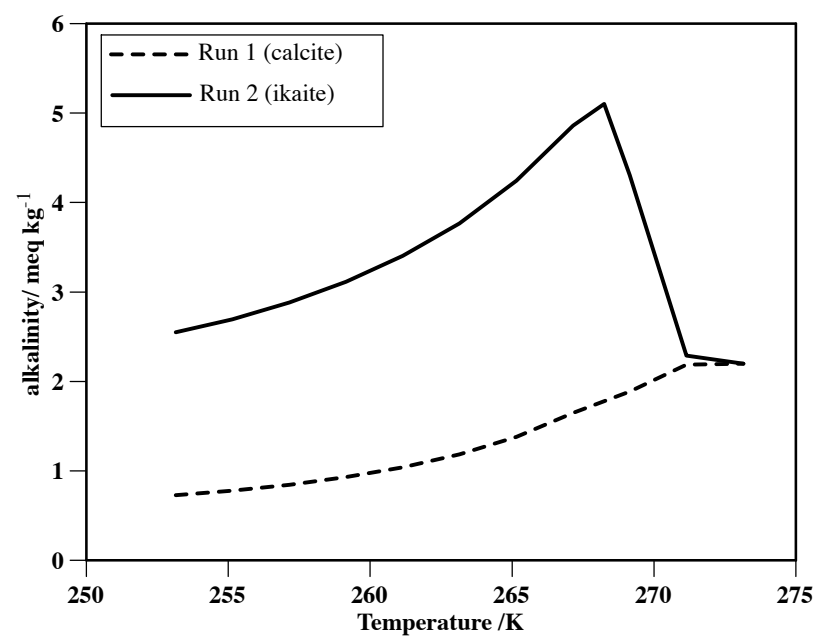

Fig. 5. Impact of the nature of the calcium carbonate salt (either calcite or ikaite) on the alkalinity of the brine in equilibrium with atmospheric $\mathrm{CO}_{2}$, as a function of temperature during the freezing of seawater.

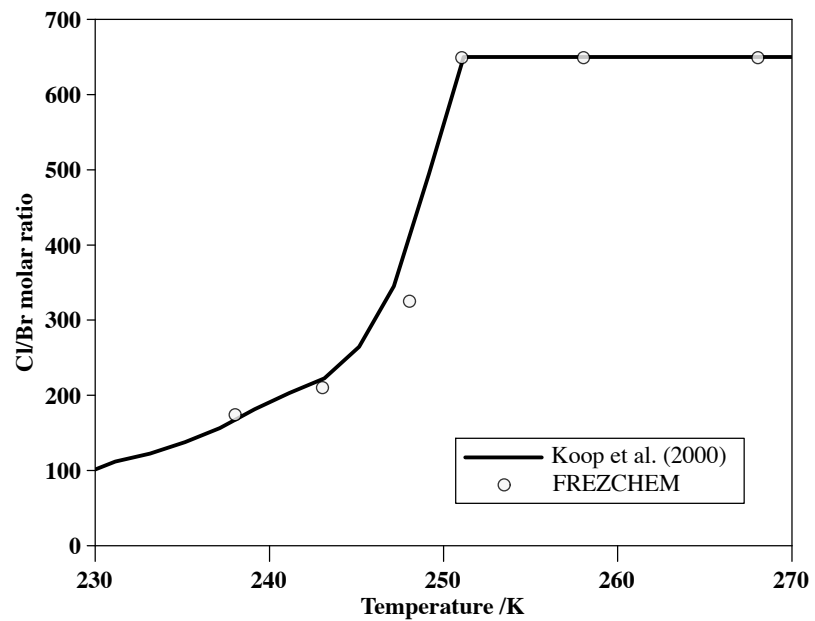

Fig. 6. Evolution of the $\mathrm{Cl} / \mathrm{Br}$ ratio as a function of temperature, assuming no precipitation of bromine-containing salt (after Koop et al., 2000), and calculated with FREZCHEM.

\subsubsection{Run 2: ikaite precipitation}

In run 2, ikaite was the only calcium carbonate polymorph allowed to precipitate. In contrast to run 1, during freezing the total alkalinity is not reduced (Fig. 5). Starting with the same alkalinity of $2.20 \mathrm{meq} \mathrm{kg}_{\text {water }}{ }^{-1}$ at $273 \mathrm{~K}$, it first increases with decreasing temperatures to reach a maximum of $5.10 \mathrm{meq} \mathrm{kg}_{\text {water }}{ }^{-1}$ at $268.25 \mathrm{~K}$. At this stage, ikaite reaches its precipitation threshold (consistent with the measurements of Dieckmann et al., 2008) and starts to precipitate. Below this temperature threshold, TA decreases steadily with temperature, but never drops below its original value.

\subsubsection{Comparison of run 1 and run 2}

If ikaite, rather than calcite, is the calcium carbonate salt which precipitates during freezing, our model results suggest that this is not accompanied by any depletion in the alkalinity of the brine, at thermodynamic equilibrium.

Ikaite precipitation begins in Fig. 5 at the point where this mineral reaches its precipitation threshold. Calcite solubility, on the other hand, rests on supersaturated $\Omega$ values (Fig. 4). Marion et al. (2008) suggest that calcite may require more supersaturation than indicated in Fig. 4 before calcite can precipitate. That would cause the calcite line (run 1) in Fig. 5 to rise, perhaps to values greater than ikaite. Experimental work on seawater freezing with monitoring of alkalinity (which is rarely done) would help clarify the alkalinity pathway.

\section{3 $\mathrm{Br} / \mathrm{Cl}$ in brine}

Koop et al. (2000) were the first to consider that differences in precipitation patterns between chloride and bromide would lead to a relative enrichment in bromide during freezing. In their study, they used data from Richardson (1976) (who did not include bromide measurements) and assumed as a first guess that bromide would not precipitate during freezing. As a result, the bromide concentration is enhanced in comparison with the initial seawater composition, for temperatures lower than $-22^{\circ} \mathrm{C}$ (Fig. 6), corresponding to the precipitation of $\mathrm{NaCl} \cdot 2 \mathrm{H}_{2} \mathrm{O}$. Simultaneously, the molal chloride/bromide ratio decreases from its "normal" value of 650 (Table 1, Millero et al., 2008), to values as low as 250 around $-30^{\circ} \mathrm{C}$. This is broadly consistent with measurements by Kalnajs and Avallone (2006), who measured $\mathrm{Cl} / \mathrm{Br}$ ratios between 269 and 367 in frost-flowers grown at temperature around $-35^{\circ} \mathrm{C}$. However, Simpson et al. (2005) did not measure such a large change in this ratio, with $\mathrm{Cl} / \mathrm{Br}$ in young (a few hours old) frost-flowers on the order of 630 (unfortunately the temperature was not given in this publication). The inclusion of the chemistry of bromide in FREZCHEM allows for a much more accurate assessment of the chemical fractionation associated with the precipitation of brominated salts. At some point, $\mathrm{Br}^{-}$(and all other soluble salts) must precipitate during the freezing process. During seawater evaporation, $\mathrm{Br}^{-}$precipitates as a minor substitute for $\mathrm{Cl}^{-}$ in halite ( $\mathrm{NaCl})$ (McCaffrey et al., 1987). The FREZCHEM model was recently parameterized to include these $\mathrm{Br}-\mathrm{Cl}$ substitution reactions at $T \geq 273 \mathrm{~K}$ (Marion et al., 2007). In our current study, we assumed that we could substitute hydrohalite $\left(\mathrm{NaCl} \cdot 2 \mathrm{H}_{2} \mathrm{O}\right)$ for halite at subzero temperatures. At $253 \mathrm{~K}$ (Fig. 6), no chloride salts have precipitated, so, the $\mathrm{Cl} / \mathrm{Br}$ ratio is still 650 (Table 1). But at 248, 243, and $238 \mathrm{~K}$, our model predicts that the $\mathrm{Cl} / \mathrm{Br}$ ratios have dropped to 326 , 211 , and 175 , respectively, because $\mathrm{Cl}^{-}$precipitates more rapidly than $\mathrm{Br}^{-}$in hydrohalite, which leads to lower $\mathrm{Cl} / \mathrm{Br}$ ratios in the solution phase. Eventually, all the $\mathrm{Br}^{-}$will precipitate in the same way as $\mathrm{Cl}^{-}$in hydrohalite, sylvite $(\mathrm{KCl})$, 
and $\mathrm{MgCl}_{2} \cdot 12 \mathrm{H}_{2} \mathrm{O}$ during seawater freezing. But most of the $\mathrm{Br}^{-}$precipitation will occur near the eutectic (i.e., 237 or $219 \mathrm{~K}$ depending on the freezing pathway, Marion et al., 1999 ) as the solution phase $\mathrm{Cl} / \mathrm{Br}$ ratio drops precipitously. Bromide is fractionated in these precipitation reactions with initial precipitates being lowest in $\mathrm{Br}$ content and final precipitates being highest in $\mathrm{Br}$ content.

\section{Atmospheric implications: a word of caution}

4.1 Applicability of the conclusions of Sander et al. (2006)

Based on available thermodynamic data and an up-to-date model handling chemical equilibria in seawater as a complex solution, this work underlines the risk of using simplified aqueous-phase chemistry in brine formed during the freezing of seawater (Marion, 2001; Sander et al., 2006). Our results indicate that the evolution of the total alkalinity of brine during freezing depends strongly on the nature of the calcium carbonate salt precipitating during freezing. If calcite is the precipitating salt, our model runs corroborate the results of Sander et al. (2006), who first predicted a quantitative depletion of the alkalinity of the brine during freezing, which would have strong implications for the onset and sustainment of ozone depletion events (Sander et al., 2006; Simpson et al., 2007; Piot and von Glasow, 2008). However this consideration has been challenged by the recent discovery that ikaite, not calcite, precipitates in seawater brine (Dieckmann et al., 2008). The implementation of this fact into the FREZCHEM model yields a very different picture in terms of the alkalinity of the brine, suggesting no depletion of the alkalinity during freezing. This result strongly contradicts the predictions of Sander et al. (2006) and casts doubts on the validity of the hypothesis originally described by these authors. The implications are twofold: first, the implementation of the "alkalinity suppression" maneuver in atmospheric models dealing with reactive bromine chemistry and ozone depletion events, following Sander et al. (2006) (e.g. Piot and von Glasow, 2008), should not be uncritically generalized, as strong doubts pertain to its reality in nature. Second and more importantly, there is an urgent need for laboratory investigations of the bromine activation reaction as a function of $\mathrm{pH}$ of the surface on which it takes place. New insights into the $\mathrm{pH}$ at the surface of frozen solutions may be gained from laboratory measurements by adapting the promising interface-sensitive fluorescent probe recently developed by Clifford and Donaldson (2007).

\subsection{Bromide enrichment in the brine}

In terms of the $\mathrm{Cl} / \mathrm{Br}$ ratio in freezing brines, the FREZCHEM results are in agreement with results linked with the hypothesis that bromine precipitation does not occur during freezing (Koop et al., 2000), because bromide is only a minor substitute in chloride salts. Although this deserves to be experimentally confirmed, this is an indication that the $\mathrm{Cl} / \mathrm{Br}$ ratio is likely to decrease when the temperature drops below $253 \mathrm{~K}\left(-20^{\circ} \mathrm{C}\right)$, consistent with some chemical observations from polar regions (Kalnajs and Avallone, 2006).

\subsection{Thermodynamic predictions and their applicability to} atmospheric chemistry

All the results presented in this article, initiated by the Sander et al. (2006) study, rely purely on thermodynamic considerations (with the notable exception of calcite supersaturation in seawater, see Sect. 3.2). There is therefore a risk pertaining to using these results as such without taking into account kinetic effects such as metastability and, in particular, supersaturation. For example, seawater freezing can proceed through two pathways, widely different in terms of eutectic temperatures and behavior of key species, solely depending on the equilibration time at each temperature step during freezing (see Marion et al., 1999, for details). It is not known which pathway corresponds to sea-ice formation. Although this does not influence the chemical composition of brine between 273 and $253 \mathrm{~K}$, predictions at lower temperatures are impaired by this unknown.

In addition, competition between kinetics (e.g. nucleation inhibition) and thermodynamics of the precipitation of calcium carbonate is likely to render the prediction of the nature of the precipitated salt quite unreproducible in nature, similar to the situation encountered in the stratosphere for the precipitation of nitric acid hydrates (Martin, 2000, and references therein). The establishment of kinetic phase diagrams, rather than thermodynamic phase diagrams for freezing seawater (Weeks and Ackley, 1982), would in particular be more useful than the latter for atmospheric applications.

Acknowledgements. We thank R. Zeebe, C. Monnin, F. Millero and F. Dominé and the atmospheric chemistry group at LGGE for stimulating discussions at earlier stages of this work. This work has benefited from useful insights from E. W. Wolff, L. Kalnajs, R. Sander and L. Kaleschke during the revision process. The timely publication by Dieckmann et al. (2008) has led to further modifications of the conclusions of this study. A generic version of FREZCHEM is freely available online at: http://frezchem.dri.edu.

Edited by: A. Pszenny

\section{References}

Bischoff, J. L., Fitzpatrick, J. A., and Rosenbauer, R. J.: The solubility and stabilization of ikaite $\left(\mathrm{CaCO}_{3} \cdot 6 \mathrm{H}_{2} \mathrm{O}\right)$ from $0^{\circ}$ to $25^{\circ} \mathrm{C}$, J. Geol., 101, 21-33, 1993.

Bottenheim, J. W., Fuentes, J. D., Tarasick, D. W., and Anlauf, K. G.: Ozone in the Arctic lower troposphere during winter and spring 2000 (ALERT 2000), Atmos. Environ., 36, 2535-2544, 2002.

Clifford, D. and Donaldson, J.: Direct experimental evidence for a heterogeneous reaction of ozone with bromide at the air-aqueous 
interface, J. Phys. Chem. A, 111(39), 9809-9814, doi:10.1021/ jp074315d, 2007.

Dieckmann, G. S., Nehrke, G., Papadimitriou, S., Göttlicher, J., Steininger, R., Kennedy, H., Wolf-Gladrow, D., and Thomas, D. N.: Calcium carbonate as ikaite crystals in Antarctic sea ice, Geophys. Res. Lett., 35, L08501, doi:10.1029/2008GL033540, 2008.

Fan, S. M. and Jacob, D. J.: Surface ozone depletion in Arctic spring sustained by bromine reactions on aerosols, Nature, 359, 522524, doi:10.1038/359522a0, 1992.

Fickert, S., Adams, J. W., and Crowley, J. N.: Activation of $\mathrm{Br}_{2}$ and $\mathrm{BrCl}$ via uptake of $\mathrm{HOBr}$ onto aqueous salt solution, J. Geophys. Res., 104, 23 719-23 727, 1999.

Gitterman, K. E.: Thermal analysis of seawater, Tech. rep., CRREL TL 287, USA CRREL, Hanover, New Hampshire, 1937.

Kalnajs, L. E. and Avallone, L. M.: Frost flower influence on springtime boundary-layer ozone depletion events and atmospheric bromine levels, Geophys. Res. Lett., 33, doi:10.1029/ 2006GL025809, 2006.

Koop, T., Kapilashrami, A., Molina, L. T., and Molina, M. J.: Phase transitions of sea-salt/water mixtures at low temperatures: Implications for ozone chemistry in the polar marine boundary layer, J. Geophys. Res., 105, 26 393-26 402, 2000.

Marion, G. M.: Carbonate mineral solubility at low temperatures in the Na-K-Mg-Ca-H-Cl-SO $4-\mathrm{OH}-\mathrm{HCO}_{3}-\mathrm{CO}_{3}-\mathrm{CO}_{2}-\mathrm{H}_{2} \mathrm{O}$ system, Geochim. Cosmochim. Acta, 65(12), 1883-1896, 2001.

Marion, G. M. and Kargel, J. S.: Cold Aqueous Planetary Geochemistry with FREZCHEM : From modeling to the search for life at the limits, Advances in Astrobiology and Biogeophysics, Springer Verlag, Heidelberg, 251 pp., 2008.

Marion, G. M., Farren, R. E., and Komrowski, A. J.: Alternative pathways for seawater freezing, Cold Regions Sci. Tech., 29, 259-266, 1999.

Marion, G. M., Kargel, J. S., and Catling, D. C.: $\mathrm{Br} / \mathrm{Cl}$ partitioning in halite and hydroalite on Mars, EOS Trans. AGU, 88(52), Fall Meet. Suppl., Abstract P21A-0223, 2007.

Marion, G. M., Millero, F. J., and Feistel, R.: Salinity/temperature ranges for applications of seawater $\mathrm{S}_{A}$-T-P models, Ocean Sci. Discuss., accepted, 2008.

Martin, S. T.: Phase transitions of aqueous atmospheric particles, Chem. Rev., 100, 3403-3453, 2000.

McCaffrey, M. A., Lazar, B., and Holland, H. D.: The evaporation path of seawater and the coprecipitation of $\mathrm{Br}^{-}$and $\mathrm{K}^{+}$with halite, J. Sediment Petrol., 57, 928-937, 1987.

Millero, F. J. and Sohn, M. L.: Chemical Oceanography, CRC Press, Boca Raton, FL, 531 pp., 1992.
Millero, F. J., Feistel, R., Wright, D. G., and McDougall, T. J.: The composition of standard seawater and the definition of the reference-composition salinity scale, Deep-Sea Res., 55, 50-72, 2008.

Morse, J. W. and Mackenzie, F. T.: Geochemistry of Sedimentary Carbonates, Elsevier Science, Amsterdam, 696 pp., 1990.

Piot, M. and von Glasow, R.: The potential importance of frost flowers, recycling on snow, and open leads for ozone depletion events, Atmos. Chem. Phys., 8, 2437-2467, 2008, http://www.atmos-chem-phys.net/8/2437/2008/.

Pitzer, K. S.: Activity coefficients in electrolyte solutions, 2nd edition, chap. Ion interaction approach : Theory and data correlation, CRC Press, Boca Raton, FL, 75-153, 1991.

Pitzer, K. S.: Thermodynamics, 3rd edition, McGraw-Hill, New York, 1995.

Platt, U. and Janssen, C.: Observations and role of the free radicals $\mathrm{NO}_{3}, \mathrm{ClO}, \mathrm{BrO}$ and $\mathrm{IO}$ in the troposphere, Faraday Discuss., 100, 175-198, 1995.

Richardson, C.: Phase relationships in sea ice as a function of temperature, J. Glaciol., 17, 507-519, 1976.

Sander, R., Burrows, J. P., and Kaleschke, L.: Carbonate precipitation in brine - a potential trigger for tropospheric ozone depletion events, Atmos. Chem. Phys., 6, 4653-4658, 2006, http://www.atmos-chem-phys.net/6/4653/2006/.

Simpson, W. R., Alvarez-Aviles, L., Douglas, T. A., Sturm, M., and Domine, F.: Halogens in the coastal snow pack near Barrow, Alaska: Evidence for active bromine air-snow chemistry during springtime, Geophys. Res. Lett., 32, doi:10.1029/ 2004GL021748, 2005.

Simpson, W. R., von Glasow, R., Riedel, K., et al.: Halogens and their role in polar boundary-layer ozone depletion, Atmos. Chem. Phys., 7, 4375-4418, 2007, http://www.atmos-chem-phys.net/7/4375/2007/.

Vogt, R., Crutzen, P. J., and Sander, R.: A mechanism for halogen release from sea-salt aerosol in the remote marine boundary layer, Nature, 383, 237-330, 1996.

Wagenbach, D., Ducroz, F., Mulvaney, R., Keck, L., Minikin, A., Legrand, M., Hall, J. S., and Wolff, E. W.: Sea-salt aerosol in coastal Antarctic regions, J. Geophys. Res., 103, 10 961-10974, 1998.

Weeks, W. F. and Ackley, S. F.: The growth, structure, and properties of sea ice, CRREL Monograph 82-1, Cold Regions Research and Engineering Laboratory, Hanover, New Hampshire, 130 pp., 1982.

Zeebe, R. and Wolf-Gladrow, D.: $\mathrm{CO}_{2}$ in Seawater: Equilibrium, Kinetics, Isotopes, Elsevier Science, Amsterdam, 346 pp., 2001. 